Gelanggang Olahraga: Jurnal Pendidikan Jasmani dan Olahraga

Volume 1, Nomor 2, Januari-Juni 2018

e-ISSN : 2597-6567

p-ISSN : 2614-607X

DOI : https://doi.org/10.31539/jpjo.v1i2.134

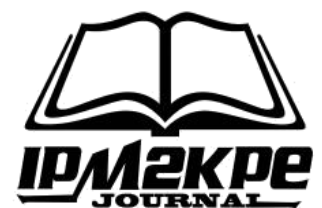

\title{
PENGARUH SENAM AEROBIC LOW IMPACT TERHADAP PENINGKATAN VO2MAX
}

\author{
Helvi Darsi \\ STKIP-PGRI Lubuklinggau \\ dr.helvidarsi.m.pd@gmail.com
}

\begin{abstract}
ABSTRAK
Penelitian ini bertujuan untuk melihat pengaruh latihan senam aerobic low impact terhadap peningkatan kapasitas VO2Max. Populasi dalam penelitian ini adalah siswa SMK Negeri 1 Curup yang mengikuti ekstrakulikuler senam aerobic. Pengambilan sampel dilakukan tekhnik "purposive randome sampling" yang berjumlah sebanyak 24 orang. Analisa dilakukan dengan cara mengukur kemampuan VO2Max melalui tes bleep test sebelum dan sesudah diberikan latihan senam aerobic low impact. Data dianalisis dengan rumus uji beda (uji t). Hasil dari penelitian diperoleh $\mathrm{t}_{\text {hitung }} 6.04>\mathrm{t}_{\text {tabel }} 1.714$ (maka $\mathrm{H} 0$ ditolak dan $\mathrm{Ha}$ diterima artinya hipotesis yang menyatakan terdapat pengaruh yang berarti antara Latihan senam aerobik low impact terhadap peningkatan VO2max siswa SMK Negeri 1 Curup diterima kebenarannya secara empiris). Hasil penelitian yakni terdapat pengaruh yang signifikan oleh latihan senam aerobic low impact terhadap peningkatan VO2Max Siswa SMK Negeri 1 Curup yang mengikuti ekstrakulikuler senam aerobic.
\end{abstract}

Kata Kunci : Aerobic Low Impact, VO2Max

\section{ABSTRACT}

This study aims to see the effect of low impact aerobic exercise on VO2Max capacity improvement. The population in this study were students of SMK Negeri 1 Curup who follow extracurricular aerobic exercise. Sampling was done by purposive randome sampling technique which amounted to 24 people. The analysis was done by measuring the ability of VO2Max through bleep test test before and after given low impact aerobic exercise. Data were analyzed by different test formula ( $t$ test). The result of the research is thitung 6.04> $t$ table 1.714 (HO is rejected and $\mathrm{Ha}$ is accepted meaning hypothesis stating there is significant influence between low impact Aerobic aerobic exercise to increase VO2max student SMK Negeri 1 Curup accepted empirically truth). The result of research that there is significant influence by low impact aerobic gymnastics exercise to increase VO2Max Student SMK Negeri 1 Curup who follow extracurricularaerobicgymnastics.

Keywords: Aerobic Low Impact, VO2Max 


\section{PENDAHULUAN}

Perkembangan dan kemajuan ilmu pengetahuan serta teknologi pada masa sekarang, memberikan perubahan-perubahan di berbagai bidang ilmu pengetahuan, termasuk dalam bidang olahraga. Dengan kemajuan ilmu pengetahuan dan teknologi keolahragaan banyak diperoleh temuan-temuan baru, baik dari segi praktek maupun teori yang menunjang dan berguna untuk meningkatkan VO2Max serta prestasi olahraga.

Dengan melakukan senam aerobik secara teratur dapat meningkatkan VO2Max, Tanpa mengalami kelelahan yang berlebihan sangat ditentukan oleh daya tahan kardiovaskuler, yaitu kemampuan sistem jantung, paru, dan pembuluh darah untuk mengangkut oksigen secara maksimal keotot. Oleh karena itu daya tahan aerobik kardiovaskuler dengan mengukur ambilan oksigen maksimal (VO2Max) merupakan indikator atau penentu VO2Max dan tingkat kesegaran jasmani seseorang.

SMK Negeri 1 Curup, merupakan salah satu lembaga pendidikan yang selalu tanggap dengan berbagai perobahan seperti senam yang telah di kembangkan. Seluruh siswa SMK Negeri 1 Curup dibekali ilmu pengetahuan dan keterampilan pendidikan jasmani dan kesehatan dengan berbagai aktifitas, karena kesadaran akan kesehatan yang merupakan unsur kesejahteraan umum yang bertujuan memelihara dan meningkatkan kesehatan dan kebugaran serta prestasi dan kualitas manusia.

Aktifitas-aktifitas pendidikan jasmani dan kesehatan yang di berikan kepada mahasiswa sebagai materi di dalam perkuliahan. Pendidikan jasmani dan kesehatan untuk kegiatan low impact aerobik atau senam dengan benturan ringan diterapkan dalam matakuliah aktifitas ritmik yaitu senam aerobic, sebagai salah satu ekstrakulikuler siswa SMK Negeri 1 Curup. Siswa yang mengikuti kegiatan ini di bekali salah satu senam kebugaran yaitu senam low impact aerobic (senam benturan ringan), dengan demikian jelas bahwa mahasiswa yang mengikuti kegiatan senam aerobik khususnya aerobic low impact memperoleh bekal keterampilan serta pengetahuan.

Berdasarkan pengamatan penulis terhadap siswa SMK Negeri 1 Curup yang mengikuti ekstrakulikuler senam aerobic, diperoleh kesan bahwa mereka belum mempunyai VO2Max yang baik. Hal ini didukung dengan hasil tes yang telah dilakukan oleh dosen yang bersangkutan. Hasil dari test tersebut adalah siswa memperolah rata-rata di bawah level 5, hal ini menyebabkan terlalu cepatnya mereka mengalami kelelahan sewaktu melakukan latihan senam low impact aerobik, banyak yang tidak aktif, tidak bersemangat dan lain sebagainya.

Disamping pengaruh latihan senam aerobic, kesegaran jasmani siswa juga dipengaruhi berbagai faktor lain seperti; 1) status gizi yang kurang seimbang, 2) kurang istirahat karena terlalu padatnya keiatan, 3) kebiasaan makan yang tidak teratur, 4) intensitas latihan, 5) pelajaran praktek setiap hari, 6) program latihan, dan 7) lingkungan tempat tinggal yang kurang sehat, misalnya rumah yang tidak memiliki ventilasi udara yang baik, banyak sampah, dan sebagainya. Dari beberapa faktor yang diduga sebagai penyebab kurang optimalnya VO2Max dan kesegaran jasmani siswa tersebut diatas, untuk itu penulis perlu melakukan penelitian secara mendalam, sehingga didapat informasi dan data yang akurat serta dapat dicarikan solusi dan jalan pemecahan nantinya. 


\section{KAJIAN TEORI}

\section{Senam Aerobik}

Senam aerobik merupakan gabungan gerakan yang energik dan kreatif, berirama cepat sesuai dengan fungsi senam aerobik itu sendiri. manfaat senam aerobik adalah meningkatkan kesehatan jantung dan stamina tubuh, tapi bila dilakukan secara tidak benar dapat menimbulkan cidera. Gerakan senam aerobik ini sebenarnya sangat cocok untuk orang yang berusia muda, 30 tahun ke bawah. karena senam ini berirama cepat dan didalamnya terdapat bermacam variasi gerakan".

Senam adalah aktifitas fisik yang dilakukan sebagai cabang olahraga tersendiri maupun sebagai latihan untuk cabang ilahraga lainnya.Berlainan dengan cabang olahraga lain pada umumnya yang mengukur aktifitas pada obyek tertentu, senam mengacu pada bentuk gerak yang dikerjakan dengan kombinasi terpadu dan menjelma dari setiap bagian anggota tubuh dari komponen-komponen kemampuan motorik seperti; kekuatan, kecepatan, keseimbangan, kelentukan agility dan ketepatan. Dengan koordinasi yang sesuai dengan tata urutan gerak yang selaras akan terbentuk rangkaian garak artistic yang menarik. Menurut Mahmudi dalam Jonni (2003) "senam berasal dari kata yunani gym yang berarti telanjang, pesenam disebut gymnast, dan tempat untuk berlatih senam disebut gymnasium". Kemudian menurut Kusuma dalam Jonni (2003) "senam merupakan olahraga yang bertujuan untuk meningkatkan kekuatan sendi dan keindahan tubuh, sehingga olahraga senam ini banyak diminati orang banyak", Jadi senam adalah suatu kegiatan yang muncul ketika si pelakunya berusaha keras untuk menguji kemampuan gerak tubuhnya dalam hubungan dengan kekuatan dan tingkat yang dipilih secara sengaja.

Secara umum aerobik dapat diartikan dengan "Oksigen", artinya adalah sikap setiap kegiatan yang berhubungan dengan aerobik sangat membutuhkan oksigen, karena olahraga ini dilakukan dalam jangka waktu yang relatif lama sehinga dalam melakukan kegiatan ini kunci utamanya adalah oksigen. Selain itu istilah aerobik tidak digunakan dalam proses penanganan secara biologis berarti proses dimana terdapat oksigen terlarut (memerlukan oksigen). Kemampuan aerobik ditentukan oleh jumlah oksigen yang dapat dikonsumsi selama kegiatan berlangsung.Untuk dapat meningkatkan VO2Max yang penting antara lain:"Kesegaran kardiovaskuler (cardiovaskuler fitnes), kesegaran kekuatan otot (strength fitnes), kesegaran keseimbangan tubuh (body compotition), dan kesegaran kelentukan (fleksibelity fitnes), serta kemampuan lain yang perlu di ukur yaitu: koordinasi (koordination), keseimbangan (balance), kecepatan (speed), kelincahan (agylity) dan daya ledak (power)."

Menurut Kristono dalam Jonni (2003) "aerobic yaitu latihan yang bertujuan untuk meningkatkan kemampuan paru-paru, jantung, serta peredaran darah, dimana oksigen merupakan faktor utama pembangkit energy pada sel-sel tubuh." Jamil (1998) memberikan istilah bahwa "aerobic to live with air", maksudnya adalah berbagai latihan fisik yang dapat memacu aktifitas jantung dan paru-paru dalam jangka waktu yang cukup lama untuk menimbulkan perubahanperubahan yang menguntungkan bagi tubuh. 
Selanjutnya Cooper dalam Kusuma (1977) menambahkan bahwa "aerobik merupakan setiap aktivitas fisik yang dapat memacu jantung dan peredaran darah serta pernapasan yang dilakukan dalam jangka waktu yang cukup lama sehingga menghasilkan perbaikan dan manfaat kepada tubuh".

Berkenaan dengan itu Irawan (1996) juga mengemukakan pengertian aerobik yaitu "jenis latihan yang banyak menggunakan oksigen, dan banyak menggunakan energi seperti karbohidrat dan lemak".

Berdasarkan hal diatas dapat disimpulkan bahwa aerobik itu merupakan jenis latihan yang banyak menggunakan oksigen,atau latihan guna meningkatkan oksigen, selain itu energi yang dibutuhkan dari proses latihan diambil dari karbohidrat dan lemak, dimana aktivitas latihan ini dilakukan dengan waktu yang lama serta melibatkan otot besar. Adapun macam-macam senam aerobik, yakni sebagai berikut

\section{Senam Low Impact Aerobic}

Senam aerobic low impact merupakan senam yang dilakukan tanpa adanya gerakan lompatan dan salah satu kaki tetap berada di lantai. Menurut Sumosardjono (1996) "senam ini di bolehkan bagi mereka yang tidak dapat mengikuti senam aerobik benturan keras, cedera pada lutut atau pergelangan kaki, karena senam aerobic low impact ini merupakan latihan yang aman dari resiko".

Kemudian menurut Lodyelen (2006) menambahkan bahwa senam aerobic low impact merupakan gerakan senam yang dilakukan dengan irama low (rendah) yaitu bentuk gerakanya lebih lambat, dengan gerakan dasar jalan, dan tidak ada gerakan melompat sama sekali. Berdasarkan uraian di atas dapat disimpulkan bahwa latihan senam aerobic low impact membutuhkan daya tahan dan kekuatan, disamping itu diutamakan keterampilan gerak dengan merangkai sesuai dengan irama musik, dengan tempo lambat dan cepat, sehingga tercapai keharmonisan gerakan.

\section{Senam High Impact Aerobic}

Senam high impact aerobik merupakan "senam aerobik yang mengarah pada gerakan lompatan, yaitu pada saat kedua kaki meninggalkan lantai" (Brick, 2002). Latihan ini di anjurkan bagi orang yang sudah biasa melakukan gerakan senam aerobik atau yang terlatih, dan gerakan ini tidak boleh dilakukan bagi orang yang pernah mengalami cedera. Menurut Sumosardjono (1996) "latihan high impact aerobik ini dapat menyebabkan cedera secara tidak sengaja pada kaki, pergelangan kaki, tulang kering dan panggul", tetapi apabila latihan aerobik high impact ini dilakukan dengan teknik yang benar, maka gerakan ini dapat dikatakan aman dan menyenangkan serta mudah melakukanya.

Berdasarkan uraian di atas dapat disimpulkan bahwa dalam melakukan latihan aerobik high impact dibutuhkan kekuatan, daya tahan tubuh dan disarankan dilakukan yang sudah terlatih fisiknya.

\section{Senam Mixed Impact Aerobic}

Menurut Sumasardjono (1996) senam mixed impact aerobic merupakan "gabungan antara gerakan low impact dan gerakan high impact". Gerakan senam ini dapat membantu meningkatkan daya tahan, memperbaiki kondisi jantung serta peredaran darah, karena otot tungkai yang di gunakan untuk melompat 
mengangkat tubuh dan menyebabkan jantung memompa lebih keras, selain itu senam mixed impact aerobic juga merupakan kombinasi rangkaian dari gerakan low impact dengan high impac, yang mana gerakan kaki suatu saat meninggalkan lantai dan kadang kala tetap berada dilantai.

Berdasarkan pendapat para ahli di atas dapat disimpulkan bahwa senam aerobik merupakan kegiatan olahraga yang mempunyai beberapa ciri khas, diantaranya gerakan senam aerobik ditampilkan dengan instruktur yang diringi dengan musik, mudah dilakukan sehingga orang mengikuti senam aerobik merasa senang dan bermanfaat bagi jantung.

\section{VO2Max}

VO2Max adalah pengambilan (konsumsi) oksigen maksimal permenit yang menggambarkan kapasitas aerobik seseorang. Menurut Junusul (2003) mengemukakan bahwa VO2Max merupakan "kemampuan maksimal dalam mengangkut oksigen selama latihan".

Selanjutnya intensitas dari latihan aerobik pada umumnya ditentukan dari kemampuanya untuk mengambil oksigen secara maksimal (VO2Max) yaitu volume oksigen terbanyak digunakan oleh seseorang dalam satu satuan waktu. lamanya latihan juga sangat tergantung pada tingkat kesegaran jasmani pada awal latihan, sehubungan dengan kapasitas aerobik tersebut diatas. Sumasardjono (1996) berpendapat bahwa "orang yang kesegaran jasmaninya tidak baik, bila diberi latihan aerobik yang intensitasnya rendah, maka kapasitas aerobiknya akan menjadi lebih baik setelah melakukan latihan maksimal berkisar antara 5-20\% dari 6-12 minggu".

Selanjutnya Nieman (2004) berpendapat bahwa "VO2Max sebagai jumlah besar oksigen yang bisa di konsumsi selama berlatih", sedangkan Anies (1995) berpendapat bahwa VO2Max merupakan "kemampuan untuk mengirimkan sejumlah darah ke otot yang sedang aktif bergerak dan kemampuan untuk mengambil oksigen yang di perlukan dari darah, untuk memberikan bahan pembakar pada waktu tubuh melakukan suatu aktifitas".

Seperti yang diketahui bahwa seseorang yang rutin beraktifitas/ berlatih akan memiliki daya tahan yang lebih baik jika dibandingkan dengan orang yang tidak pernah beraktivitas, daya tahan yang baik tentunya didukung oleh VO2 max yang baik. Hal ini disebabkan dengan rutinya seseorang melakukan aktivitas/ berlatih akan mempercepat tubuh dalam beradaptasi terhadap beban yang diberikan saat beraktivitas, sehingga mampu bekerja secara kontinue tanpa mengalami yang berlebihan.

Berdasarkan pendapat diatas maka dapat disimpulkan bahwa VO2Max merupakan kemampuan tubuh buntuk mengambil oksigen semaksimal mungkin dalam melakukan aktivitas.

\section{METODE PENELITIAN}

Jenis penelitian ini adalah eksperimen semu (quasi eksperimen). Metode ini digunakan atas dasar pertimbangan bahwa sifat dari penelitian yang digunakan merupakan suatu proses dengan cara memberikan perlakuan terhadap sampel yaitu test VO2max (BLEEP TEST) dimana tes dilakukan kepada sampel sebelum dan sesudah sampel mendapat perlakuan, perlakuan yang di berikan kepada 
sampel adalah latihan senam aerobic low impact, yakni dengan frekuensi latihan sebanyak 16 kali perlakuan

Penelitian ini dilaksanakan di SMK Negeri 1 Curup dengan sample yaitu siswa putra yang mengambil ekstrakulikuler senam aerobik. Sample ditarik dengan teknik purposive random sampling yakni "jika jumlah populasi lebih dari 100 orang, maka pengambilan sampel sebanyak 23\%" (Arikunto 2006). Untuk lebih jelasnya pengambilan sampel dilakukan dengan cara mengurutkan hasil test mulai dari yang tertinggi ke yang terendah, kemudian dari hasil rata-rata diambil sampel sebanyak $23 \%$ di atas rata-rata dan $23 \%$ di bawah rata-rata. Dengan demikian sampel berjumlah 24 orang dari total populasi putra.

Untuk mendapatkan data dalam penelitian ini, Data dianalisa dengan teknik analisis deskriptif, penelitian ini menggunakan rumus t-test .

$$
r=\frac{\mid \overline{X_{1}}-\overline{X_{2} \mid}}{\sqrt{\frac{\sum D^{2}-\frac{\left(\sum D\right)^{2}}{N}}{N(N-1)}}}
$$

Keterangan :

$$
\begin{aligned}
& \overline{X_{1}} \quad=\text { Rata-rata (Mean) sampel pertama } \\
& \overline{X_{2}} \quad=\text { Rata-rata (Mean) sampel kedua } \\
& \text { D = beda antara sampel pertama dan kedua } \\
& D^{2} \quad=\text { Kuadrat beda } \\
& \sum D=\text { Jumlah semua beda } \\
& \sum D^{2} \quad=\text { Jumlah semua beda yang sudah di pangkat dua } \\
& \mathrm{N} \quad=\text { Jumlah pasangan sample }
\end{aligned}
$$

\section{HASIL PENELITIAN}

Analisis Data Penelitian

Analisis data dalam penelitian ini dimaksud untuk melihat karakteristik $\mathrm{VO}_{2}$ Max sebelum dan sesudah di lakukannya latihan senam aerobic low impact. Untuk lebih jelasnya dapat dilihat sebagai berikut:

Tabel I.

Rerata hitung, standar deviasi, nilai minimum dan Nilai maksimum, tes wal dan tes akhir

\begin{tabular}{ccccc}
\hline No. & Kelompok & Statistik & Tes Awal & Tes Akhir \\
\hline \multirow{4}{*}{1} & Latihan Senam & Mean & 34.04 & 38.11 \\
& Aerobik Low & Std. Dev & 2.77 & 3.26 \\
& Impact & Min & 29.9 & 33.2 \\
& & Max & 41.8 & 45.9 \\
\hline
\end{tabular}


Berpedoman dari tabel I, nilai kedua kelompok $\mathrm{VO}_{2} \mathrm{Max}$ untuk tes awal didapat nilai mean 34.04, standar deviasi 2.77, nilai minimum 29.9, dan maksimum 41.8 dan untuk tes akhir untuk $\mathrm{VO}_{2} \mathrm{Max}$ didapat mean 38.11, standar deviasi 3.26, nilai minimum 33.2, dan maksimum 45.9. Untuk lebih jelasnya penjelasan di atas dapat dilihat pada diagram bawah ini:

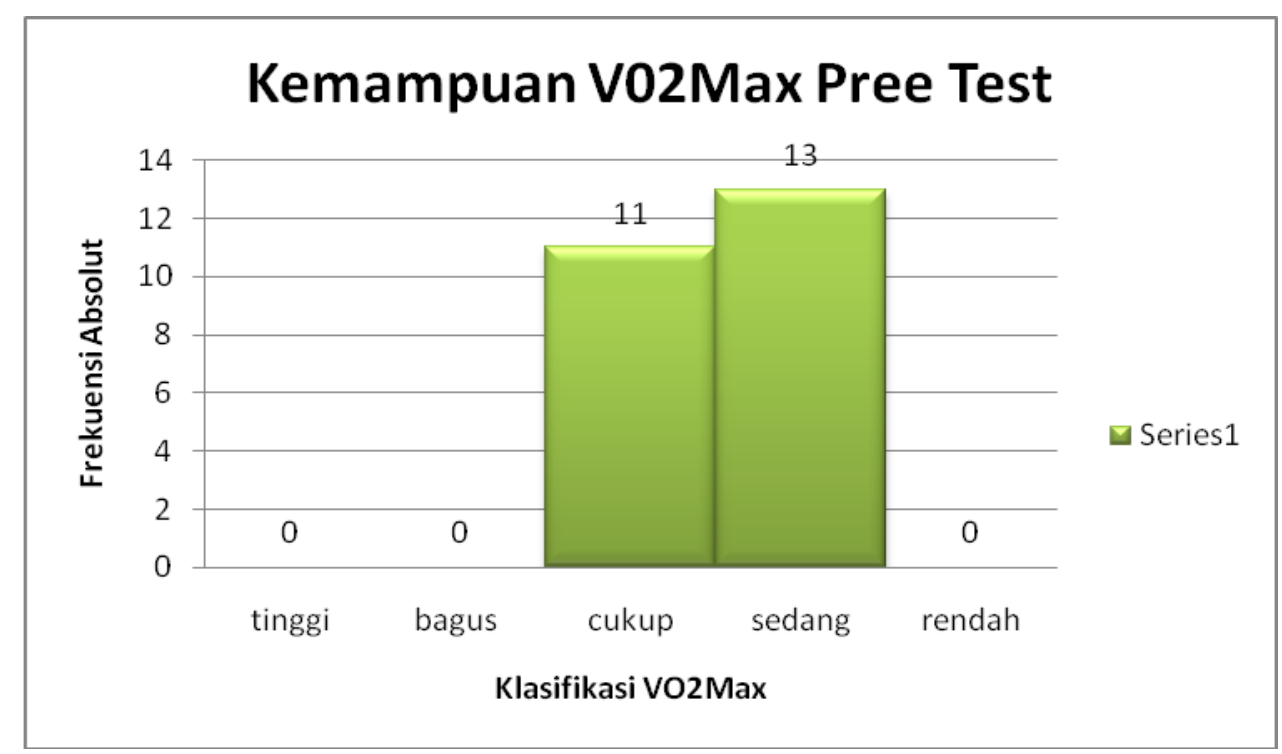

Gambar. 1 Histogram $\mathrm{VO}_{2} \mathrm{Max}$ pree test

Berdasarkan gambar di atas dapat dilihat 11 orang siswa SMK Negeri 1 Curup memiliki kemampuan $V_{2}$ max pada kategori cukup, 13 orang siswa SMK Negeri 1 Curup memiliki kemampuan Vo $\max$ pada kategori sedang. Serta tidak ada mahasiswa yang berada pada kategori pada tinggi, bagus, dan rendah.

Sementara itu histogram kemampuan Vo, max setelah dilakukanya Latihan Senam aerobic low impact dapat dilihat pada gambar berikut ini:

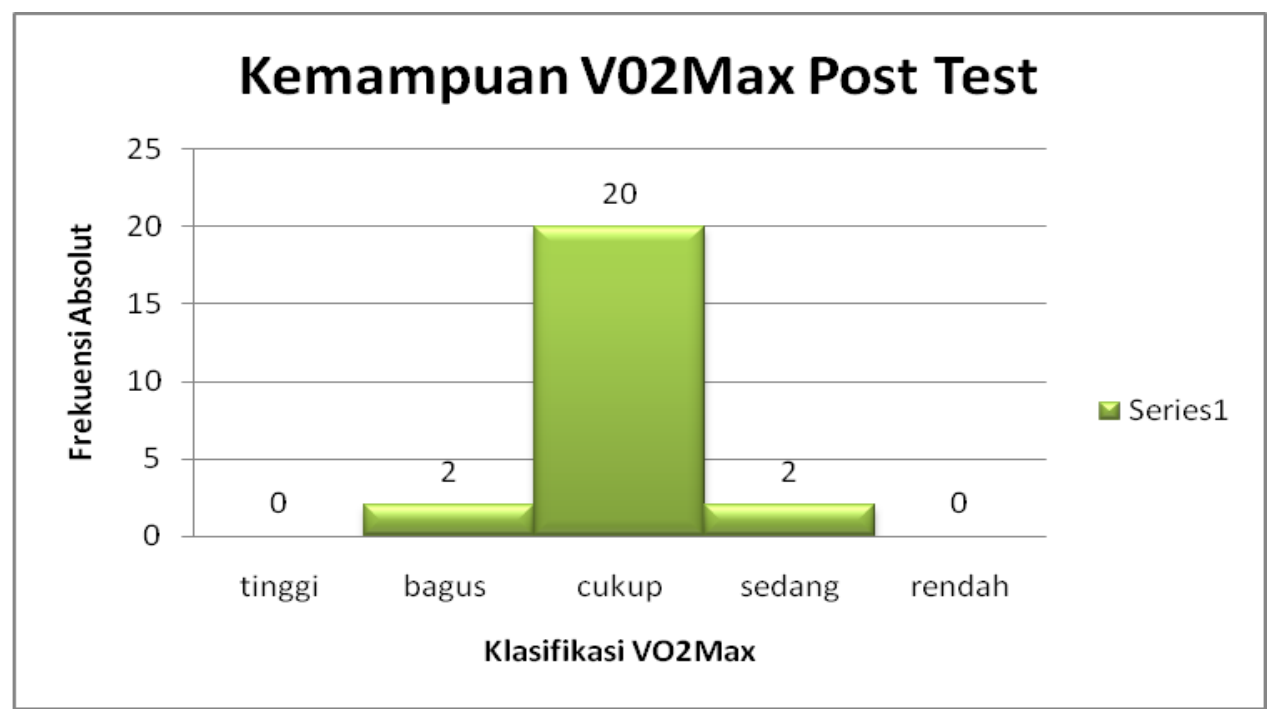

Gambar 2. Histogram $\mathrm{Vo}_{2} \max$ post test 
Dari diagram di atas dapat dilihat 2 orang siswa SMK Negeri 1 Curup memiliki kemampuan $V_{2} \max$ pada kategori bagus, 20 orang siswa SMK Negeri 1 Curup memiliki kemampuan $\mathrm{Vo}_{2}$ max pada kategori cukup, 2 orang siswa SMK Negeri 1 Curup memiliki kemampuan $V_{2} \max$ sedang dan tidak ada siswa SMK Negeri 1 Curup memiliki kemampuan $V_{2} \max$ pada kategori tinggi, dan rendah.

\section{Uji Normalitas}

Hasil uji normalitas dari data berat badan dari tes awal dan tes akhir menggunakan uji Liliefors menunjukkan bahwa $\mathrm{L}_{\text {hitung }}<\mathrm{L}_{\text {tabel. }}$. Artinya data berdistribusi normal. Hasil lengkap uji Liliefors dapat dilihat pada tabel berikut:

Tabel 2

Uji Normalitas Data Penelitian (uji Liliefors)

\begin{tabular}{cccccc}
\hline Kelompok & & \multirow{2}{*}{ Tes Awal } & $\mathrm{L} 0=0.172433$ & Ltabel & Ket \\
\cline { 1 - 1 } $\begin{array}{c}\text { Latihan Senam } \\
\text { Aerobik Low } \\
\text { Impact }\end{array}$ & \multirow{2}{*}{ Uji lilierfors } & & $\begin{array}{c}\text { Pada } \alpha \\
(0.05)=\end{array}$ & Normal \\
\cline { 3 - 4 } & & \multirow{2}{*}{ Tes akhir } & $\mathrm{L} 0=0.124533$ & 0.1815 & \\
\hline
\end{tabular}

\section{Pengujian Hipotesis}

Hipotesis dalam penelitian ini adalah terdapat pengaruh yang berarti antara latihan senam aerobic low impact terhadap VO2max siswa SMK Negeri 1 Curup.

Analisis terhadap kelompok latihan senam aerobik low impact, diperoleh $\mathrm{t}_{\text {hit }} 6.04>\mathrm{t}_{\mathrm{tab}}$ (1.714). Ini menyatakan bahwa rerata pengukuran variabel sangat kuat (signifikan) dan terdapatnya peningkatan secara nyata dari perlakuan yang diberikan, untuk lebih jelasnya dapat dilihat pada tabel di berikut ini.

Tabel 3

Data Kelompok Latihan Senam Aerobic Low Impact

\begin{tabular}{cccc}
\hline Data penelitian & $\mathrm{t}_{\text {hit }}$ & $\mathrm{t}_{\mathrm{tab}}$ & Kesimpulan \\
\hline $\begin{array}{c}\text { VO2max (Data Awal) } \\
-\end{array}$ & 6.04 & 1.714 & Signifikan \\
$\operatorname{VO2max}$ (Data Akhir) & & & \\
\hline
\end{tabular}

Berdasarkan pengolahan data yang telah dilakukan dengan menggunakan uji $t$, didapat hasil dari pengujian tersebut dengan skor $t_{\text {hit }} 6.04$, sedangkan $t_{\text {tab }}$ yang dilihat pada daftar uji $\mathrm{t}$ pada taraf 0,05 dengan derajat kebebasan $(\mathrm{dk})=\mathrm{n}-1$ $=24-1=23$ adalah 1.714. karena $t_{\text {hit }}>t_{\text {tab }}$ atau $6.04>1.714$, maka H0 ditolak dan Ha diterima artinya hipotesis yang menyatakan terdapat pengaruh yang berarti antara latihan senam aerobic low impact terhadap peningkatan VO2max siswa SMK Negeri 1 Curup diterima kebenarannya secara empiris.

\section{PEMBAHASAN}

Perhitungan Uji t hanya dapat digunakan untuk menguji perbedaan mean dari dua sampel yang diambil dari suatu populasi yang berdistribusi normal, serta data yang diperoleh dalam skala interval atau rasio. Dari perhitungan uji t antara pengaruh latihan senam aerobic low impact terhadap berat badan diperoleh $t_{\text {hit }}$ 6.04 untuk $\mathrm{t}_{\text {tab }}$ pada taraf signifikan $\alpha=0,05$ yaitu 1.714 . Berarti dalam hal ini 
terdapat pengaruh yang berarti antara latihan senam aerobic low impact terhadap peningkatan VO2max siswa SMK Negeri 1 Curup.

Senam aerobic low impact merupakan senam yang dilakukan tanpa adanya gerakan lompatan dan salah satu kaki tetap berada di lantai. Menurut Sumosarjono (1996) "senam ini dibolehkan bagi mereka yang tidak dapat mengikuti senam Aerobik bentruran keras, cedera pada lutut atau pergelangan kaki, karena senam aerobic low impact ini merupakan latihan yang aman dari resiko".

Lodyelen (2006) menambahkan bahwa "senam aerobic low impact merupakan gerakan senam yang dilakukan dengan irama low (rendah) yaitu bentuk gerakannya lebih lambat, dengan gerakan dasar jalan dan tidak ada gerakan lompat sama sekali".

Berdasarkan uraian di atas dapat disimpulkan bahwa latihan senam aerobik low impact membutuhkan dayatahan dan kekuatan, disamping itu diutamakan keterampilan gerak dengan merangkai sesuai dengan irama musik, dengan tempo lambat dan cepat, sehingga tercapai keharmonisan gerakan.

Dari hasil analisis diatas dapat diambil kesimpulan bahwa latihan senam aerobic low impact dapat membuat perubahan yang berati dari kemampuan VO2max seseorang, apabila latihan senam aerobik low impact dilakukan dengan benar dan pemberian dosis latihan yang tepat. Penerapan program latihan senam aerobic low impact yang kurang terencana akan mengakibatkan perubahan berat badan yang ingin dicapai dari siswa SMK Negeri 1 Curup tidak akan ada artinya.

Pada penelitian ini dapat dilihat bahwa hanya ada sedikit perubahan $\mathrm{VO}_{2}$ siswa SMK Negeri 1 Curup karena pemberian program yang hanya $1 \mathrm{x}$ dalam satu minggu. Menurut Anies (1995:74) menyatakan bahwa VO 2 max dalam latihan maksimal berkisar 5-20\% setelah berlatih 8-16 minggu dengan frekuensi latihan 2 -3 kali dalam seminggu, karena apabila frekuensi latihan dikurangi maka tidak ada peningkatan dalam latihan tersebut. Oleh karena itu pada penelitian ini dapat disumpulkan bahwa kemungkinan besar siswa SMK Negeri 1 Curup mengalami peningkatan $\mathrm{VO}_{2} \mathrm{Max}$ bukan karena program yang dibuat oleh instruktur, melainkan karena siswa memiliki aktifitas rutin diluar program yang dibuat oleh instruktur dan sebagian besar mahasiswa merupakan mayoritas atlit dari berbagai cabang olahraga.

Dalam pelaksaaannya latihan senam aerobic low impact yang diterapkan pada penelitian ini berdurasi 16 kali pertemuan. Diharapkan kepada para peserta senam untuk dapat melakukan latihan senam aerobic low impact dengan kontiniu atau tidak terputus-putus dengan frekuensi 2-3 kali dalam semingggu, untuk mendapat hasil yang sempurna dari proses latihan tersebut.

Diharapkan pada penelitian selanjutnya untuk menerapkan program yang sempurna, agar hasil dari penelitian menjadi maksimal. Senam aerobic low impact merupakan senam yang tidak memberikan beban terlalu besar, rangakaian geraknya banyak melangkah dan cenderung lateral (samping), tetapi disini kondisi fisiknya juga dilihat seperti: kekuatan, daya tahan (aerobik maupun anaerobik), kelincahan dan kelentukan sehingga secara tidak langsung akan meningkatkan VO2 max. Peningkatan tersebut dapat terjadi setelah menjalankan latihan sesuai dengan program yang sudah dibuat sebelumnya, sehingga efek latihan itu akan berdampak terhadap kesegaran jasmani dan $V O 2$ max para pesertanya. 


\section{SIMPULAN}

Berdasarkan analisis data dan pembahasan, maka dapat dikemukakan kesimpulkan sebagai berikut. Hasil yang diperoleh dari latihan senam aerobic low impact mempunyai pengaruh yang signifikan terhadap peningkatan $\mathrm{Vo}_{2}$ max, ini ditandai dengan hasil yang diperoleh yaitu $t_{\text {hit }} 6.04$ untuk $t_{\text {tab }}$ pada taraf signifikan $\alpha=0,05$ derajat kebebasan $(\mathrm{dk})=\mathrm{n}-1=24-1=23=1.714$, ini artinya terdapat pengaruh yang berarti antara latihan senam aerobic low impact terhadap kemampuan Vo $_{2}$ max Siswa SMK Negeri 1 Curup.

\section{DAFTAR PUSTAKA}

Anies. (1995). VO2Max ukuran kesegaran jasmani.jakarta.

Arikunto, S. (2006). Prosedur Penelitian.Jakarta: PT Rineka Cipta.

Brick, L. (2007). Bugar Dengan Senam Aerobik. Jakarta :fajar interpratama Offset.

Hairy, J. (2003). Daya Tahan Aerobik. Jakarta: Direktorat Jendral Olahraga. Departemen Pendidikan Nasional.

Irawan, A. (1996). Senam Aerobik. Jakarta: Pustaka Setia

Jamil, R. (1998). Kebugaran Jasmani. Jakarta: PT Gramedia

Jonni. (2003). Senam Aerobik. Padang, FIK-UNP

Kusuma. (1977). Senam Aerobik. Bandung: Alphabeta

Ladyelen, B. (2006) Aerobikyuk'.http;ladyelen,blogspot.com/2006/08/aerobik Yuk,html.

Nieman, D., C. (2004). Kebugaran dan Kesehatan Anda.Padang :FIK-UNP.

Sumosardjono. (1996). Sehat dan Bugar. Jakarta: PT.Gramedia Pustaka utama 